\title{
REVERSE LOGISTICS AND MANAGEMENT OF WASTE PRODUCTS: THE NIGERIAN MANUFACTURING FIRMS EXPERIENCE
}

\section{Bilqis Bolanle Amole, Sulaimon Olanrewaju Adebiyi, Kayode Kingsley Arogundade}

(1) Accounting and Business Administration Department, Distance Learning Institute, University of Lagos, Akoka, Lagos, Nigeria

(2) Department of Business Administration, University of Lagos, Akoka, Lagos, Nigeria

(3) Department of Business Administration, Ekiti State University, Ado-Ekiti, Ekiti State. Nigeria

Bilqis Bolanle Amole Accounting and Business Administration Department, Distance Learning Institute, University of Lagos, Akoka, Lagos, Nigeria

Article info

Paper category: Original Scientific Paper Received: $28.5 \cdot 2018$. Accepted: 28.9.2018. JEL classification: C8, L6o, M1, $Q_{5}$

Keywords

Reverse logistic; Product recovery; Recycling Waste Product,; Waste Management; Manufacturing Industry; Nigeria 


\section{ABSTRACT}

Purpose. The paper explores reverse logistics activities such as product return, reuse of materials, and waste disposal impacts on the management of waste products in the $\mathrm{Ni}$ gerian manufacturing companies. This is with a view to examining the awareness of reverse logistics to the management of waste products in Nigeria and determines the importance of reverse logistics activities and process to the management of waste products of Nigeria manufacturing firms.

Methodology. Using a cross-sectional survey research design, 300 staff of selected manufacturing firms that deal with waste product were selected in Lagos and a well-structured and validated questionnaire was administered. From this, 250 copies were returned, while 246 were valid for the purpose of analysis. Data generated were analysed using descriptive statistics, analysis of variance test of significance and Friedman rank test.

Findings and Implication. The findings revealed that the respondents convinced that their reverse logistics activities arising from return of goods may be as very important to developing efficient and effective management of waste products of Nigeria manufacturing firms. The results also indicates that reverse logistics is highly significant in achieving the organizational goals $(p<0.05)$, company's future success $(F=8.18, p<0.05)$, the functioning of a manufacturing company $(p<0.05)$ and strategically positioning the company. The study therefore recommends the need for a growing focus on various sections of reverse logistics processes in waste products' management of manufacturing company in order to achieve organisational goal and enhances sustainable business performance. 


\section{INTRODUCTION}

The importance of good environment cannot be overemphasized as it contributes to the healthy living of the people in any society. Nigeria as a developing country cannot be an exception to the green environment campaign globally since it is an advocacy for ensuring healthy living for people. Waste, on the other hand, is inevitable wherever human and material resources interact or where human being uses material resources. However, the need to live in a clean and healthy environment is sine qua non for an average citizen in the country.

Manufacturing companies transport goods to their customers through various modes (air, land, rail and water). Implied in the movement of goods from one place to another is an economic activities aimed at satisfying human needs and wants profitably. Oftentimes, they dome firms do not give consideration to the backward movement of goods otherwise known as "reverse logistics". This may be due to the fact that the returns would stand for substantial cost, rather than profit. A few chief executives even consider return as a major failure of their system (Dowlatshahi, 2000; Meyer, 1999).

As a process, reverse logistics has to do with companies becoming more conscious and committed to the environment, especially in the way they engaged in recycling, reusing and cutting down on the number of material used. Taken together, reverse logistics means reducing materials in forward system such that few materials flow-back; there is this possibility of the reuse of materials and the facilitation of recycling. The steps taken to reduce waste in the environment start from the product design phase and cover the entire product life cycle. In turn, this will make for the minimization of downstream waste and giving rooms for product to go backwards along the business chain for product remanufacture, reuse and resale to market.

In Nigeria, most manufacturing companies focus essentially on the sales of products to the final consumer. Primarily, they do this from an opinion that after the sales or use of product, responsibilities are taken-off these companies or manufacturers on the return of the product. In most cases, the used products are discarded thereby causing harmful effects to the environment. The used products were either discarded or destroyed causing negative effects to the environment. Evident and common in this regard are sachet, plastics water, bottles/can drinks which are common to most Nigerian as well as other industrial products.

In this $21^{\text {st }}$ century, it is not enough for organizations to engage in marketing but more importantly, societal marketing is good for both the organization and all its stakeholders in which the reverse logistic framework preaches. There is need to encourage our companies or manufacturers to develop environmentally friendly products with their consumers, therefore companies should be more involved in collecting, dismantling and upgrading used products and packages materials. If there are more advanced systems and processes, goods returned can be recorded and properly 
managed. Even so, they can be put for sale at liquidation centers. Alternatively, the goods can be broken down into different major parts, which can possibly lead to the cutting down of costs, increase in profit and improvement of consumer service.

Reverse logistics processes are not part of the core processes of companies that are still starting up a reverse chain, and therefore the necessary capabilities are yet to be acquired and developed. In order to develop these capabilities, one must first know which capabilities are of importance to the reverse activities. Furthermore, companies that want to gather these specific reverse logistics capabilities, need to invest resources, in learning is important as well as a commitment to learning which will foster a learning orientation within the company (Normann, 1985).

When there is an atmosphere of knowledge building and sharing, the company will more easily to build capabilities. As a result, learning will have an impact on the company's ability to acquire and develop capabilities and will have an effect on the reverse logistics activities. To realize the goal of sustainable development in organizations especially manufacturing companies that focus on the environmental and economic goals, there is a necessity for the implementation of reverse logistics (Dowlatshahi, 2010).

Lau and Wang (2009) posited that engaging in reverse logistics can help reduce waste and increase profit through an effective recycling process in the developing countries. Furthermore, the increase in awareness on environmental issues and the benefit of recycling places more pressure on firms to create a better reverse logistics strategy. Leite (2009) made the assertion that in order to have a good goodwill among their customers or corporate citizenship, it is essential for the firms to abide by the extant regulations and emphasize the protecting of the environment.

In view of the above analysis, this study aims at examining the impact of reverse logistics on the Management of Waste Products in selected Nigerian Manufacturing Companies. While the specific objectives are to;

(1) examine the awareness of reverse logistics to the management of waste products in Nigeria

(2) examine the importance of reverse logistics activities and process to the management of waste products of Nigeria manufacturing firms.

(3) determine the challenges of reverse logistics on the management of waste products for Nigeria manufacturing firms

(4) evaluate the impact of reverse logistics in managing waste products in the $\mathrm{Ni}$ gerian Manufacturing Companies.

The remainder of this paper is structured as follows: Section 2 defining forward and reverse logistics, its major differences, its importance and summaries of relevant works on reverse logistics; Section 3 describes the methodology used. Succeeding this is the data analysis and discussion of results in Section 4 and lastly, Section 
5 discusses the conclusion based on the findings from the study. Recommendations were made for policy implications.

\section{LITERATURE REVIEW}

The literature review focuses on issues relating to reverse logistics and management of waste products.

\subsection{Definition of forward logistics and its difference to reverse logistics}

Stock (1992) defines logistics as the capacity to manage materials from where they originate to the point of consumption. Tibben-Lembke and Rogers (2002) later expanded this definition as management of information flow and not only the management of physical flow. This process of direct logistics has been widely regarded as Forward Logistics. Also, there is what is regarded as reverse logistics process. This process is similar to forward logistics process, only that it is concerned with movement of materials from the point of consumption to the point of origin where product are been produced. This reverse order flow is what has be regarded Reverse Logistics.

The known areas of dissimilarities between forward and reverse logistics can be found in high cost and complexity of reverse logistics. Da, Hua \& Zhang, (2004) and Parvenov (2005), identified popular issues connected to reverse logistics such as:

- Operating with a small or sub-standard and warehouse facilities;

- Uncertainty in the recovery system; and

- Inability of tracking incoming merchandise, which does not allow for cross docking;

Additionally, the poor method of placing products into a warehouse hinders the possibility of returned merchandise to be adequately allocated and shipped. Other factors include;

- High cost of setting up the reverse logistics process to aid the repackaging of returned goods for resale;

- Cost of disposing of unserviceable items and others;

Usually, these are the challenges of reverse logistics. However, these problems can be surmounted and converted to competitive advantage, if there is an efficient reverse logistic system (Ravi \& Shankar, 2005; Bernon \& Cullen, 2007).

\subsection{Definitions of reverse logistics}

Over the years, the concept of reverse logistics has continued to change. In the 1980 , it was taken to be the movement goods from the consumer to the producer through a recognized distribution channel. However, in the 1990s, new approaches to conceiving the concept were initiated by other scholars (Stock, 1992; Carter \& Ell- 
ram, 1998). In their new approaches, reverse logistics was projected as the returned materials focusing not only on technical and economic benefits, but environmental efficiency as well. In their approach, the interest on environmental efficiency is to guarantee the right consumption by reusing and recycling of industrial goods.

Reverse Logistics (RL) or Reverse Distribution (RD) is defined as "the logistics management skills and activities involved in reducing, managing, and disposing of hazardous waste from packaging and products." It includes reverse distribution, which causes goods and information to flow in the opposite direction from normal logistic activities (Kroon \& Vrijens, 1995; Pohlen \& Farris, 1992).

The Council of Management (CLM) defines reverse logistics as "the process of planning, implementing, and controlling the efficient, cost-effective flow of raw materials, in-process inventory, finished goods and related information from the point of consumption to the point of origin for the purpose of recapturing value or proper disposal" (Rogers \& Tibben-Lembke, 1998).

Subsequently, Stock and Lambert (2001) revealed that reverse logistics is the area of business logistics concerned with adding economic and environmental values to industrial goods so as to enable the reintegration of product lifecycle as secondary materials. Also reverse logistics is seen as the movement of goods and services in a contrary position in the supply chain, for the purpose of enabling proper disposal. This process usually involves the processing of returned merchandise caused by damage, restocking, seasonal inventory, salvage recalls and excess inventory. It is also involves packaging and shipment materials from the consumer to the seller. A process like this would involve recycling programs, hazardous material programs and disposition of obsolete material and asset repossession (Rogers \& Tibben-Lembke, 2001). According to Kleindorfer, Singhal, Van and Luk (2005), reverse logistics involves re-use and recovery of products, so as to limit the negative effects on the environment and waste disposal.

\subsection{Importance of reverse logistics}

Reverse logistics as important environmental dimensions and a few aspects dealing with value reclamation (Carter \& Ellram, 1998). Reverse logistics can be of immense value in remanufacturing, repair, reconfiguration and recycling, which can translate to profitable business opportunities (Giunti \& Andel, 1995; South, 1998). Reverse logistics also affords firms a huge opportunity to distinguish their roles from that of customers, and indicates how the handling of a company 's returns is often assessed by customers as an important consideration, when a future purchase takes place (Daugherty, Myers, \& Richey, 2002). To these scholars, a well-planned reverse logistic system can promote long-lasting relationship for mutual benefits (satisfying needs of consumers and profit for the producers). In like manner, customers are more likely to patronise retailers who perform above other retailers on the handling of returns. 
Essentially, logistics is major factor that enhances a company`s achievements in different as aspects of business. It is widely acknowledged that reverse logistics plays a key role in a company`s performance and customer relations (Daugherty, Richey, Genchev \& Chen, 2005). However, as pointed out by Autry, Daugherty and Richey (2001), it is often under-considered as a strategic option firms to gain economic and environmental benefits, with its strategic value neglected. Businesses' reluctance in executing reverse logistics program can be attributed the following:

The traditional preoccupation of companies with limited logistics and the tendency to hide inventory mistakes are pointed out as potential factors that can hinder a company from committing substantial resources to reverse logistics. Another factor is inability to recognise areas where there are potential benefits (Daugherty et al., 2001; Saccomano, 1997).

Moreover, Richey, Stefan and Patricia (2005) stated that physical process usually requires "a series of intricate multilayered steps" involving raising returns authorization, printing label, determining appropriate product handling and disposition, and organising transportation.

The unwillingness to commit resources to returns in the chain of supply gives rise to opportunity for the companies to establish their business strategies. In regard to this, Stock, Speh, \& Shear (2002) reason that though reverse logistics is often viewed as "costly sideshow" to the regular business operations, it should receive much more awareness than it is now. It is also proposed that reverse logistics should "be seen as an opportunity to build competitive advantage".

Similarly, Richey, et al. (2005) advised companies to strengthen their competiveness through operational performance and financial benefits gained from commitment of more resources to reverse logistics. Moore (2005) avers that many benefits can be derived from effective an effective logistic program. Such benefits include: reuse or packaging, reduction of excess inventory of raw materials and old equipment disposal.

\subsection{Waste Management}

Waste management decisions that dwell on matters that need urgent attention and matters that may arise that and needs strategic planning and implementation. Setting up and making facilities to run efficiently to enable collection, recycling, treatment and disposal of waste local communities can be quite expensive. For instance, it requires large financial investments, considerable operation and maintenance cost to run sanitary landfills and incinerator plants. Thus, community solid waste management can be very costly but not avoidable. For example, building and operating sanitary landfills and incineration plants require huge investments and incur substantial operation and maintenance costs. Companies are hereby advised to adopt and integrate waste management that emphasizes prevention, reduction, 
and recycling of waste. As this is better than authorities having to meet-up with the demand of managing the increase number of waste through method of treatment and disposal. By way of the state resources that could be used for other equally important citizen welfare activities (education, health and security) not to be wasted (Manual, 2010). When applied, the financial burden of cities in the management of waste will be reduce, likewise the demand on landfill requirements. In our world today, resources are scarce. There are limited natural resources from raw materials. Same way, financial resources are often not enough. There is also difficulty of getting land for waste disposal especially in urban setting like Lagos, Nigeria. In light of these, man must think of alternative procedures for managing waste. Authorities in cities are enjoined to generate and implement policies that take care of resources efficiently and remanufacturing if need be. This is necessary in order to provide a clean and safe environment for their citizens and future generations.

In short, the best practices for waste minimization are by waste avoidance, waste recycling, waste treatment and waste disposal. Similarly, the key principles governing hazardous waste disposal are polluter pays, the duty of care, avoidance and minimization and best practicable environmental option (Chandak, 2005).

\subsection{Empirical review on reverse logistics}

Early researchers on reverse logistics appear to focus more on an extensive view. Many works of researchers engaged in the whole process of reverse flow. Krupp (1993) for instance, looked at bill-of-materials (BOM) restructuring and the development of bills of material to serve challenges of remanufacturing. Suggested in Krupp `s study is sale forecasting, which, to him, has to be constructed to show the uncertainty and variety of core returns for both old and net parts. Usually, after the sales of products to consumers, manufacturers are no longer responsible for products. Most products dump causing damage to the environment. Now, consumers and government authorities hope that manufacturers would reduce the wastes that are derived from their products. In this $21^{\text {st }}$ century, waste disposal and management are beginning to gain substantial attention. Emphasis is now placed on recovery, due to high cost and burdens that come with disposal. Firms are now more involved in collecting and dismantling and upgrading of waste products and packaging of materials (RevLog, 1998).

Furthermore, Webb (1994) drew attention to the idea of "green movement". He pointed out that environmental concerns have in determining the direction of activities of reverse logistics; such activities as packaging regulation and customer preferences are few of the reverse logistics activities that deal with environmental considerations.

A few other studies focused on reverse logistics, particularly issues regarding transportation, distribution and inventory management. Similarly, others like White (1994) accounted for the relevance of reverse logistics for handling of material. To 
him, these consist of moving, storing, protecting and controlling materials. In addition, he noted that protection is key to handling material system. On the other hand, Dave (1995) considered return management as the most reliable way of differentiating consumer service and firm `s competitive advantage. Following this he posited that most required re-engineering factors are return process and warehouse operations. On their part, Fuller \& Allen (1996) assert that waste is an indispensable by-product of resource-conversion processes in any economy searching for success. As one of the programs that compliment sustainable development, efforts have been made to recycle waste. To aid this endeavour, systematic procedure of using information is very important. This will enable the development of reverse channels for recycling materials and lobbying efforts to support the passage of recycling bill in a nation.

Some scholars consider reverse logistics as practical quantitative models especially that of Clegg, Williams and Uzsoy (1995), came up with a linear programming model. They did this so as to ascertain the effects of recycling and remanufacturing on the operation of manufacturing firms. Further, they advised firms to apply this in analyzing the viability of parts recovered during operations involving remanufacturing.

In the above, there exist a range of quantitative models that have been developed by scholars (Fleischmann et al., 1997; Guide Jr, Srivastava, \& Spencer, 1996; Kroon $\&$ Vrijens, 1995). The developed models can be deployed to various kinds of logistics practices, like extension of product life cycle, protecting product and so on. Also, it is important to note that the application of reverse logistics is another area of logistic that is popular other developed and developing nations. Kroon and Vrijens, (1995) averred that "a change in attitude towards the environment is an absolute necessity". On this basis, they suggested a whole process of "collection, recycling and reuse of products and materials".

Cespón, Castro and Lundquist (2009) identified a generic configuration of reverse logistic strategies in manufacturing companies from the Cuban central area. As a result, their research detected the existence of three generic reverse logistic strategies which are: recapturing value, environmental and commercial strategies.in which other manufacturing companies in other countries can adopt.

Starostka-Patyk and Grabara (2010) proposed an elaborated descriptive model of reverse logistics processes in enterprises managing industrial waste. The work was carried out in Poland in Silesia region on six different enterprises managing industrial waste, this particular model is based on reverse logistics literature studies and practical activities of waste management in enterprises managing industrial waste. Both scholars, in their paper presented a much-cleared role of reverse logistics processes in enterprises managing industrial waste. It revealed fascinating connection between logistics and waste, as well as an interesting element of sustainable development conception for achieving ecological goals.

Kinobe, Gebresenbet, and Vinneras (2012) reviewed a paper stating the procedure of reverse logistics and the present state of waste management in developing 
countries using Uganda as their case study. They found out that in a relative sense, reverse logistics is a new area of research, dealing with condemned goods and recollection of products for onward return to manufacturers. It is practise generally in developed economies, than in developing ones. This is due to the fact that in developing countries, value is hardly placed on reverse products.

In the work of Silva, Reno, Sevegnani, Sevegnani and Truzzi (2013), they discussed reverse logistics, and in the process, accounted for a packaging strategy that will help to minimize waste generation and boost the competitive status of the firm they considered by managing cost and resource consumption and reducing the effects of waste products on the environment. The methods created helped to engender protection of products exported and reduce the generation of waste by consumers. In terms of environmental impact, the most reliable model was the returnable packaging. This is in view of the fact that it has a reduced environmental impacts, especially when placed side-by-side with disposal packaging model. As a model, reverse logistics has proven to be beneficial because it of impacts on technical, economic and environmental aspect of business sustainability.

A study that was carried out in Kenya by Kariuki \& Waiganjo (2014) evaluated the factors affecting the implementation of reverse logistics in manufacturing businesses in Kenya. The study revealed legislation, economics, corporate citizenship and collaboration among supply chain partners are factors that can hinder the implementation of reverse logistics in manufacturing companies in Kenya. The study concluded that organizations that want to practice reverse logistics should put these identified factors into consideration so as to ensure organizational success.

Tepprasit and Yuvanont (2014) examined the different impacts of logistics management and how effective they can be, using the electronic industry in Thailand as a case study. In doing so, this study applies a mixed method of qualitative and quantitative research. Twenty directors were interviewed at different popular manufacturing firms. The questions focused on five basic elements of logistic management: - product design and choice of materials; transportation and movement; manufacturing; packaging; and communication. These five elements were studied in relation to their impacts on reverse logistics. In their investigation, they initiated a method that is entirely different from the traditional theory, highlighting the fact business environment in Thailand is more complex than many other countries. The results of their investigation turn out to be relevant to managers in the electronic manufacturing industry, because they aid in mapping out areas of relevance that can make them uplift the standard of logistic management in their various companies.

In light of this review, researchers are motivated then embarked on this work since studies have been done on reverse logistics in various aspects in developing and developed countries but there is limited or rarity of studies on reverse logistics in countries like Nigeria. This study sets out to investigate the reverse logistics practices on waste products of manufacturing companies in Nigeria. 


\section{METHODOLOGY}

This study used a cross-sectional research design which will allow the researcher to investigate reverse logistics and companies' management of waste products. This study covers manufacturing firms in Nigeria. Simple random sampling technique was used to select 300 staff of manufacturing firms involve in waste products management in the sample firms. Primary data were collected with the aid of structured questionnaire. The population of the study comprises of all staff of manufacturing companies dealing with waste products in Nigeria. Lagos state was selected because; it is the center of all manufacturing activities in Nigeria. The sampling frame of this study is selected from the Manufacturing Association of Nigeria (MAN) which shows that over 2800 manufacturing companies were listed. Three sub-sectors of Manufacturing industry were randomly selected which include the Food and Beverages industry, Paper Processing industry and Automobile Industry. A well validated questionnaire was administered to respondents who include staff from various departments that are involved in the production and distribution activities of the sampled firms. Data were measured on 5-point Likert scale and analysed using descriptive statistics, analysis of variance test of significance and Friedman rank test. Level of awareness and importance of reverse logistics were analysed using percentages. Analysis of variance was used to test the significance of reverse logistics to Nigeria manufacturing industry while Friedman Test was used to rank the challenges to the management of waste products. Friedman is a non-parametric test useful in ranking observation with chi-square test statistics as the diagnostic criteria.

\section{RESULTS AND DISCUSSION}

Awareness of reverse logistics to the management of waste products in Nigeria

To find out the level of information on reverse logistics in managing waste products, the respondents were asked to choose between 5 options that represent 5 different levels from very high to very low level of awareness. The Figure 1 gives the distribution of the level of awareness of participants over the 5 levels. The results indicated that generally, a high percentage $(52 \%)$ of respondents had a low level of awareness of reverse logistics in waste management processes. About $35 \%$ of respondents were highly aware of reverse logistics while $13 \%$ of respondents had no awareness. In the course of the discussion, most of the respondents, however, explained that although they had limited amount of information on the term, once the concept of reverse logistics became clear to them, they realized that they had involved themselves in at least certain activities relating to reverse logistics in their company. 
Figure 1.: Level of awareness of reverse logistics by staff of manufacturing firms in Nigeria

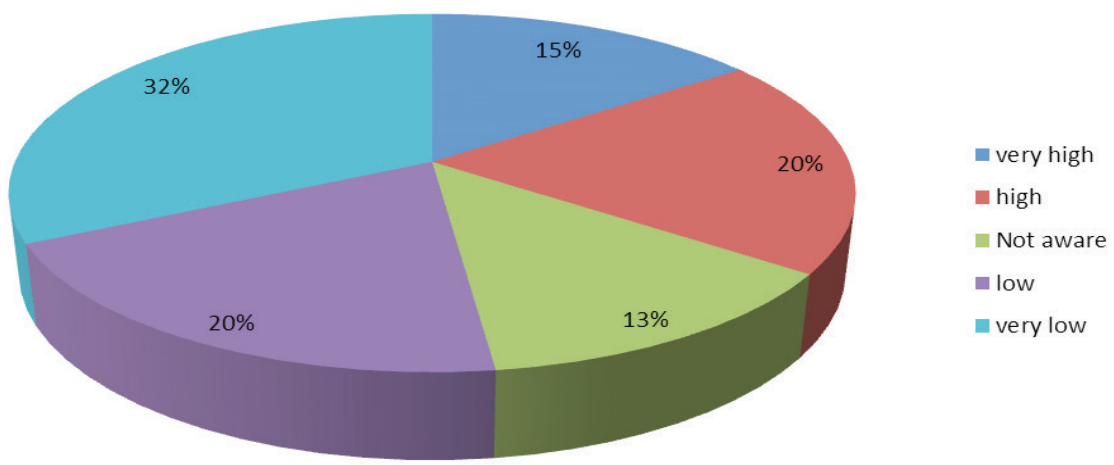

Source: Autors.

The importance of reverse logistics activities and process to management of waste products of Nigeria manufacturing firms

Responses obtained showed that reverse logistics plays an important role in the overall success of an organization (see Table 1.). Achieving objectives within reverse logistics are central to the attainment of organizational goals. Very high percentage $(83 \%)$ of respondents totally agreed to the importance of logistics framework to achieving goals and objective. In response to whether reverse logistic is relevant for success, $29 \%$ and $23 \%$ of respondents, respectively, strongly agreed and agreed that reverse logistics is important for company's future success. This represented about $52 \%$ level of agreement to the importance of reverse logistics. Meanwhile, about $40 \%$ disagreed that reverse logistics is important for future company's success. In any organization, proper functioning of operating system is paramount. Most (51.8\%) of the respondents agreed that reverse logistics is important for the functioning of their manufacturing company and as well important (59\%) in the strategy of the company. As the results suggest, most of the respondents believe that their reverse logistics process can be considered as very important to developing efficient and effective management of waste products of Nigeria manufacturing firms. This means there is a growing focus on various sections of reverse logistics processes in waste products' manufacturing company. 
Table 1.: Description of importance of reverse logistics to Nigeria manufacturing industry

\begin{tabular}{|c|c|c|c|c|c|c|}
\hline $\mathrm{S} / \mathbf{N}$ & Questions & SA & A & $\mathbf{U}$ & D & SD \\
\hline 1 & $\begin{array}{r}\text { Achieving } \\
\text { objectives within } \\
\text { reverse logistics } \\
\text { contributes to } \\
\text { achieving the } \\
\text { organizational } \\
\text { goals (Imp 1) }\end{array}$ & $45 \%$ & $38 \%$ & $2 \%$ & $11 \%$ & $6 \%$ \\
\hline 2 & $\begin{array}{r}\text { Reverse logistics } \\
\text { is important for } \\
\text { your company's } \\
\text { future success } \\
(\operatorname{Imp} 2)\end{array}$ & $29 \%$ & $23 \%$ & $8 \%$ & $18 \%$ & $22 \%$ \\
\hline 3 & $\begin{array}{r}\text { Reverse logistics } \\
\text { is important for } \\
\text { the functioning } \\
\text { of your company } \\
\text { (Imp 3) }\end{array}$ & $29.6 \%$ & $22.2 \%$ & $9.7 \%$ & $15.2 \%$ & $23.3 \%$ \\
\hline 4 & $\begin{array}{r}\text { Reverse logistics } \\
\text { plays an } \\
\text { important role } \\
\text { in the strategy of } \\
\text { your company } \\
\text { (Imp 4) }\end{array}$ & $18.7 \%$ & $40.3 \%$ & $1.8 \%$ & $13.4 \%$ & $25.8 \%$ \\
\hline
\end{tabular}

Source: Authors Computation.

Results in Table 2. showed the statistical significance $(p<0.05)$ of measures of reverse logistics to the manufacturing company. The results indicated that reverse logistics highly significant to achieving the organizational goals $(p<0.05)$, company's future success $(\mathrm{F}=8.18, \mathrm{p}<0.05)$, the functioning of a manufacturing company $(\mathrm{p}<$ 0.05 ) and strategically positioning the company. Agood reverse logistics process will increase the overall success of firms and also the speed of delivery which in turn will improve the quality of service.

Table 2.: Significance test of strategic importance of reverse logistics to Nigeria manufacturing industry

\begin{tabular}{|l|r|r|r|r|r|}
\hline \multicolumn{1}{|c|}{ Source } & Partial SS & Df & \multicolumn{1}{c|}{ MS } & \multicolumn{1}{c|}{ F } & \multicolumn{1}{c|}{ Prob > F } \\
\hline Model & 208.06 & 16 & 13.003 & $13.09^{* * *}$ & 0.0000 \\
Imp1 & 48.763 & 6 & 8.127 & $8.18^{* *}$ & 0.0000 \\
Imp2 & 10.392 & 3 & 3.464 & $3.49^{* *}$ & 0.0166 \\
Imp3 & $49.65^{*}$ & 4 & 12.413 & $12.49^{* *}$ & 0.0000 \\
Imp4 & 54.875 & 3 & 18.292 & $18.41^{* *}$ & 0.0000 \\
Residual & $228.5^{3 *}$ & 230 & 0.9936 & & \\
Total & $436.59^{*}$ & 246 & 1.7747 & & \\
N=246 & & & & & \\
\hline
\end{tabular}




\begin{tabular}{|l|l|l|l|l|l|}
\hline \multicolumn{1}{|c|}{ Source } & Partial SS & Df & MS & F & Prob $>$ F \\
\hline $\begin{array}{l}\text { Root MSE }= \\
0.9968\end{array}$ & & & & & \\
Rsquared $=$ & & & & & \\
O.4766 & & & & & \\
Adj & & & & & \\
R-squared $=$ & & & & \\
O.4401 & & & & & \\
\hline
\end{tabular}

Source: Authors' Computation.

Challenges of Reverse Logistics on the management of waste products for Nigeria manufacturing firms

Various challenges were associated with reverse logistics in the management of waste products for Nigeria manufacturing firms. Using Friedman's rank test which was significant at $5 \%$ level, the results showed that customers' negative perception of returning the products ranked as the biggest challenge (4.06) followed by high cost associated with reverse logistics (3.74), Uncertainties relating to product returns (3.44), Lack of collaboration with supply chain partners in reverse logistics (3.4.0), Lack of top management awareness of the importance of reverse logistics (3.23) and Lack of information on its importance (3.13).

Table 3.: Challenges of Reverse Logistics on the management of waste products

\begin{tabular}{|l|r|}
\hline \multicolumn{1}{|c|}{ Challenges } & Mean rank \\
\hline High cost associated with reverse logistics & 3.74 \\
Lack of information on its importance & 3.13 \\
Uncertainties relating to product returns & 3.44 \\
Lack of top management awareness of the importance of reverse & 3.23 \\
logistics & 3.4 .0 \\
Lack of collaboration with supply chain partners in reverse logistics & 4.06 \\
Customers' negative perception of returning the products & \\
Chi-Square = 81.87 & \\
Df =5 & \\
Asymp. Sig. $=0.000$ & \\
\hline
\end{tabular}

Source: Authors' Computation.

The impact of reverse logistics on the management of waste products in the $\mathrm{Ni}$ gerian manufacturing companies

The impact of reverse logistics activities such as product return, reuse of materials, and waste disposal on the management of waste products in the Nigerian manufacturing companies was examined and the results were presented in Table 4. The overall model is significant suggesting that reverse logistics impact significantly ( $p<0.05$ ) on the management of waste products in the Nigerian manufacturing companies. Furthermore, the results showed that the activities of reverse logistics such as 
product recovery $(\mathrm{p}<0.05)$ and product reuse of materials $(\mathrm{p}<0.05)$ have a significant impact on the management of waste products.

The findings align with Lindahl, Sundin, Östlin, and Björkman, (2006) who considered product recovery as one of the processes of reuse and recycling. An important objective of products recovery is to retrieving the value of the product when such product no longer fulfils the expected value. Product recovery has also been viewed as a joint activity involving remanufacture, reuse and recycling usually did to recover the economic value in materials and enhance solid waste management (Gungor \& Gupta, 1999).

Table 4.: Overall model of impact of reverse logistics on the management of waste products

\begin{tabular}{|l|r|r|r|r|r|r|}
\hline \multicolumn{1}{|c|}{ Source } & Partial SS & Df & MS & & \multicolumn{1}{c|}{ F } & \multicolumn{1}{c|}{ Prob > F } \\
\hline Model & 64.1101289 & 20 & & 2.137004 .3 & 4.34 & 0.0000 \\
Product recovery & 6.32898843 & 7 & 1.26579769 & & $2.57^{*}$ & 0.0276 \\
Product reuse & 19.2120768 & 5 & 4.80301921 & & $9.75^{*}$ & 0.0000 \\
Waste disposal & 4.98012617 & 8 & .830021028 & & 1.69 & 0.1254 \\
Residual & 111.275085 & 226 & .492367633 & & & \\
Total & 175.385214 & 246 & .685098492 & & & \\
\hline
\end{tabular}

Source: Authors' Computation.

\section{CONCLUSION AND RECOMMENDATIONS}

This study examines the impacts of reverse logistic activities on the management of waste products, reflecting the Nigeria manufacturing experience. Data were generated through questionnaire administration to staff of manufacturing companies dealing with waste products in Nigeria. The results of data analysed indicated an overall significant impact of reverse logistics on the management of waste products in the Nigerian manufacturing companies.

The study concludes that reverse logistics process is very important in developing efficient and effective management of waste products of Nigeria manufacturing firms. The study found reasons to conclude based on the results that reverse logistics is highly significant in achieving the organizational goals, company's future success, the functioning of a manufacturing company and strategically positioning the company especially in the face of current rising costs of manufacturing in Nigeria. The study therefore recommends the need for a growing focus on various sections of reverse logistics processes in the management of waste products' of manufacturing company in order to achieve organisational goal and enhances sustainable business performance. Proper implementation of reverse logistic activities as a National policy and in the Nigeria`s manufacturing industry in particular will positively affect the economic life of the firms, and the general well-being of the environment, thereby ensuring sustainable development of the country. 


\section{REFERENCES}

Autry, C. W., Daugherty, P. J., \& Richey, R. G., The challenge of reverse logistics in catalogue retailing. International Journal of Physical Distribution \& Logistics Management, 31(1), (2001): 26-37

Bernon, M., \& Cullen, J., An integrated approach to managing reverse logistics. Int. J. Logistics-Res. App. $10,(2007): 41^{-}-56$

Carter, C. R., \&Ellram, L. M.,. Reverse logistics: a review of the literature and framework for future investigation. Journal of Business Logistics, 19(1), (1998): 85

Cespón, M. F., Castro, R. C. \& Lundquist, J., Empirical Study on Reverse Logistic Strategies in the Manufacturing Sector in the Central Area of Cuba. Journal of Operations and Supply Chain Management, 2(2), (2009): $72-82$

Chandak, S. P., Trends in Solid Waste Management - Issues, Challenges, and Opportunities presented at the International Consultative Meeting on Expanding Waste Management Services in Developing Countries, 18-19 March 2010, Tokyo, Japan (2010).

Clegg, A. J., Williams, D. J., \& Uzsoy, R. Production planning for companies with remanufacturing capability. (1995): 186-191

Council of Logistics Management (CLM). What it's all about. Oak Brook, IL: Council of Logistics Management, 4-6, (1998).

Daugherty, P. J., Autry, C. W., \& Ellinger, A. E. Reverse logistics: the relationship between resource commitment and program performance. Journal of Business Logistics, 22(1), (2001): 107

Daugherty, P. J., Myers, M. B., \& Richey, R. G. Information support for reverse logistics: the influence of relationship commitment. Journal of Business Logistics, 23(1), (2002): 85

Daugherty, P. J., Richey, R. G., Genchev, S. E., \& Chen, H. Reverse logistics: superior performance through focused resource commitments to information technology. Transportation Research: Part E, $41(2),(2005): 77$

Da, Q., Huang, Z., \& Zhang, Q., Current and future studies on structure of the reverse logistics system: a review. Chinese Journal Management Science, 12, (2004): 131-138

Dawe, R. L. Reengineer your returns. Transportation \& Distribution, 36(8), (1995): $7^{8}$

Dowlatshahi, S., Developing a theory of reverse logistics. Interfaces, 3०(3), (2000): 14.3-55

Dowlatshahi, S. A Cost-benefit analysis for the design and implementation of reverse logistics systems: Case studies approach. International Journal of Production Research, 48(5), (2010): 1361-1380

Fleischmann, M., Bloemhof-Ruwaard, J. M., Dkker, R., van der Laan, E., van Nunen, J. A. E. E., \& van Wassenhove, L. N. Quantitative models for reverse logistics: A review. European Journal of Operational Research, 103(1), (1997): 1-17

Fuller, D. A., \& Allen, J. Materials recycling and reverse channel networks: The public policy challenge. Journal of Macro marketing, 16(2), (1996): 52

Giunti, R., \& Andel, T. Advance with reverse logistics. Transportation \&Distribution, 36(2), (1995): 73.

Guide Jr, V. D. R., Srivastava, R., \& Spencer, M. S. Are production systems ready for the green revolution? Production \& Inventory Management Journal, $37(4)$, (1996): 70 
Gungor, A. \& Gupta, S.M. Issues in environmentally conscious manufacturing and product recovery: a survey. Computers and Industrial Engineering, 36, (1999): $811-85^{3}$

Kariuki, P.W. \& Waiganjo, E.W. Factors affecting adoption of reverse logistics in the Kenya manufacturing sector: A case study of coastal bottlers company. International Journal of Academic Research in Business and Social Sciences, 4. (9), (2014): 4-97

Kinobe, J. R., Gebresenbet, G. \& Vinnera, B., Reverse logistics related to Waste Management with emphasis on developing countries-A review paper, Journal of Environmental Science and Engineering, $1,(2012): 1104-1118$

Kleindorfer, P. R., Singhal, K. Van W., \& Luk N, Sustainable Operations Management. Product and Operations Management, 14,(4), (2005): 4,82-492

Kroon, L. \& Vrijens, G. Returnable Containers: An Example of Reverse Logistics. International Journal of Physical Distribution and Logistics Management, 25(2), (1995): 56-68,

Krupp, J. A. G. Structuring bills of material for automotive remanufacturing. Production \& Inventory Management Journal, 34, (4), (1993): 46

Lau, K. H. \& Wang, Y. Reverse logistics in the electronic industry of China: A case study supply chain management: An International Journal, 14.(6), (2009): 447-65

Leite, P. R. Logística Reversa - Meio Ambiente e Competitividade. 2ed. São Paulo: Prentice Hall (2009).

Lindahl, M., Sundin, E., Östlin, J. \& Björkman, M. Concepts and definitions for product recovery: analysis and clarification of the terminology used in academia and industry, Innovation in Life Cycle Engineering and Sustainable Development, (2006): 123-138

Manual, S. A Guide for Sustainable Urban Development in the 21st Century. Shanghai, China, (2010).

Meyer, H., Many happy returns. Journal of Business Strategy, 20(4), (1999): 27-31

Moore, R., Reverse logistics-the least used differentiator. UPS Supply Chain Solutions (2005).

Murphy, P. R. A preliminary study of transportation and warehousing aspects of reverse distribution.

Transportation Journal. 35, (1986): 12-21

Normann, R., Developing capabilities for organizational learning. Organizational strategy and change, $(1985): 217-24.8$

Parvenov, L., Expert Insight: Best practices in warehouse returns. Supply Chain Digest. (2005).

Pohlen, T. \& M.T. Farris, Reverse logistics in plastics recycling, International Journal of Physical Distribution and Logistics Management, 22(7), (1992): 34-47

Ravi, V. \& Shankar, E., Analysis of interactions among the barriers of reverse logistics. Technol. Forecast. Soc. 72, (2005): 1011-1029

RevLog, The European Working group on Reverse Logistics. http://www.fbk.eur.nl/OZ/REVLOG/, accessed 27/10/2017(1998).

Richey, R. G., Stefan, E. G., \& Patricia, J. D. The role of resource commitment and innovation in reverse logistics performance. International Journal of Physical Distribution \& Logistics Management, $35(4)$, $(2005): 233-257$

Rogers, D.S., \& Tibben-Lembke, R. S., Going backwards: reverse logistics trends and practices. The University of Nevada, Reno, Center for Logistics Management, Reverse Logistics Council. (1998). 
Rogers, D.S. \& Tibben-Lembke, R. S. An examination of reverse logistics practices.Journal of Business Logistics. 22(2), (2001): 129-148

Saccomano, A. Many happy returns. Traffic World, 249(7), (1997): 22

Starostka-Patyk, M \& Grabara, J. K. Reverse Logistics Processes in Industrial Waste Management as an Element of Sustainable Development. Annales Universitatis Apulensis Series Oeconomica, 12(2), (2010): $698-707$

Silva, D. A. L. Reno, G. W. S. Sevegnani, G., Sevegnani, T. B. \& Truzzi, O. M. S. Comparison of disposable and returnable packaging: a case study of reverse logistics in Brazil, Journal of Cleaner Production 47, (2013): $377^{-387}$

South, S. Managing returned freight. Inbound Logistics, 18(12), (1998): 48

Stock, J.R., Reverse Logistics. Council of Logistics Management, Oak Brook, IL(1992).

Stock, J.R., Lambert, D.M., Strategic Logistics Management. McGraw-Hill,New York. (2001).

Stock, J.R., Speh, T.W. \& Shear, H.W. Many happy (product) returns. Harvard Business. Review, 8o, (2002): 16-17

Tepprasit, P. \& Yuvanont, P. The Impact of logistics management on reverse logistics in Thailand's electronics industry. International Journal of Business and Information, 10(2), (2014): 257-271

Tibben-Lembke, R.S., \& Rogers, D.S., Differences between forward and reverse logistics in a retail environment. Supply Chain Management. International Journal. 7, (2002): 271-282

Webb, L. Green purchasing: forging a new link in the supply chain American Society of Agricultural Engineer, 1(6), (1994):14,-18

White, J. A. Reverse logistics moves forward. Modern Materials Handling, 49(1),(1994): 29

Yamane, T. Statistics, an introductory analysis (2nd ed.). New York: Harper and Row. (1967). 